\title{
Do changes in riparian zones affect periphyton growth and invertebrate colonization on rocky substrates in Atlantic Forest streams?
}

\author{
Walace P. Kiffer Jr. ${ }^{1,2}$ (1) https://orcid.org/0000-0002-0847-9031 \\ Thaís Z. Giuberti' (1D https://orcid.org/0000-0001-9520-1013 \\ Karoline V. Serpa ${ }^{1,2}$ (D) https://orcid.org/0000-0001-5568-2940 \\ Flávio Mendes' 1 h https://orcid.org/0000-0002-2263-0498 \\ Marcelo S. Moretti ${ }^{1,2}$ [D https://orcid.org/0000-0003-1994-2105
}

\footnotetext{
1. Laboratório de Ecologia de Insetos Aquáticos, Universidade Vila Velha, Av. Comissário José Dantas de Melo, 21, 29102-920 Vila Velha, ES, Brasil.

(walace.kiffer@uvv.br; thais.zg@gmail.com; karolserpa@hotmail.com; f.mendes.eco@gmail.com; marcelo.moretti@uvv.br)

2. Programa de Pós-Graduação em Ecologia de Ecossistemas, Universidade Vila Velha.
}

Received 17 November 2017

Accepted 21 March 2018

Published 11 June 2018

DOI 10.1590/1678-4766e2018014

\begin{abstract}
We evaluated the growth of periphyton and colonization of sterilized cobbles by invertebrates in three coastal streams of the Atlantic Forest (Southeast Brazil) that differ in the conservation level of riparian zones. Because of differences in light availability and water temperature, we hypothesized the growth of periphytic algae would be higher in the most altered stream. Consequently, invertebrate assemblages would differ among streams. Cobbles with similar sizes were ashed and incubated for 7, 15, 30, 45 and 60 days in the studied streams. Despite periphyton growth was faster in the most altered stream, contents of chlorophyll- $a$ did not differ among streams. A total of 954 individuals (98\% insects) belonging to 36 taxa was found. Invertebrate density was higher and increased throughout the experiment in the preserved stream, while invertebrate biomass was higher on the initial sampling intervals ( 7 and 15 days). A stream effect on invertebrate assemblages was observed after the $15^{\text {th }}$ day and 17 taxa were found only in the preserved stream. Leptophlebiidae (Ephemeroptera), Hydroptilidae, Helichopsychidae, Leptoceridae (Trichoptera) and Orthocladiinae (Diptera) showed specificities with the assemblages found in the preserved stream and no taxa proved to be an indicator of the assemblages found in the altered streams. These results showed that changes in the riparian zones of Atlantic Forest streams did not affect the content of chlorophyll- $a$ on rocky substrates, but the growth of periphyton influenced the density and structural composition of invertebrate assemblages. Our findings partially support the proposed hypothesis and conform to the notion of the importance of periphyton community for the colonization of exposed substrates by invertebrates and for evaluating the consequences of anthropogenic changes in ecosystem functioning and aquatic communities.
\end{abstract}

KEYWORDS. Periphytic biomass, invertebrate assemblages, exposed substrates, anthropogenic changes, tropical streams.

RESUMO. As alterações nas zonas ripárias afetam o crescimento do perifíton e a colonização de substratos rochosos por invertebrados em riachos de Mata Atlântica? O crescimento do perifíton e a colonização de seixos esterilizados por invertebrados foram avaliados em três riachos costeiros de Mata Atlântica (Sudeste do Brasil) que diferem no estado de conservação das zonas ripárias. Devido a diferenças na disponibilidade de luz e temperatura da água, foi hipotetizado que o crescimento das algas perifíticas seria maior no riacho mais alterado. Consequentemente, as assembleias de invertebrados iriam diferir entre os riachos. Seixos com tamanhos similares foram incinerados e incubados por 7, 15, 30, 45 e 60 dias nos riachos estudados. Apesar do crescimento do perifíton ter sido mais rápido no riacho mais alterado, os teores de clorofila- $a$ não diferiram entre os riachos. Um total de 954 indivíduos ( $98 \%$ insetos) pertencentes a 36 táxons foi encontrado. A densidade de invertebrados foi maior e aumentou ao longo do experimento no riacho preservado, enquanto a biomassa de invertebrados foi maior nos intervalos iniciais de amostragem (7 e 15 dias). Um efeito dos riachos nas assembleias de invertebrados foi observado após o $15^{\circ}$ dia e 17 táxons foram encontrados somente no riacho preservado. Leptophlebiidae (Ephemeroptera), Hydroptilidae, Helichopsychidae, Leptoceridae (Trichoptera) e Orthocladiinae (Diptera) apresentaram especificidades com as assembleias encontradas no riacho preservado e nenhum táxon foi indicador das assembleias encontradas nos riachos alterados. Estes resultados demonstraram que alterações nas zonas ripárias de riachos de Mata Atlântica não afetaram os teores de clorofila- $a$ em substratos rochosos, mas o crescimento do perifíton influenciou a densidade e a composição estrutural das assembleias de invertebrados. Estas observações suportam parcialmente a hipótese proposta e estão em conformidade com a noção da importância da comunidade perifítica para a colonização de substratos expostos por invertebrados e para a avaliação das consequências das alterações antrópicas no funcionamento dos ecossistemas e nas comunidades aquáticas.

PALAVRAS-CHAVE. Biomassa perifítica, assembleias de invertebrados, substratos expostos, alterações antrópicas, riachos tropicais. 
Periphyton communities play an important role in the energy flow of freshwater ecosystems, with high ecological importance in the food chains of these environments (Feminella \& HaWkins, 1995; Brito et al., 2006). These communities may influence the growth, development, survivorship and reproduction of many heterotrophic organisms, especially fish, aquatic insects and crustaceans (Moulton et al., 2004; Ceneviva-Bastos \& CASATTI, 2014).

Algae are the most-studied component of periphyton and are responsible for much of the gross primary production in stream ecosystems (SCHNECK et al., 2013; Moulton et al., 2015). The presence of these primary producers alters the structure of the aquatic environment; the algae remove nutrients from the water column, minimize the effects of water flow on exposed substrates, and contribute to sediment stabilization (LARNED, 2010). The biomass of periphytic algae may be influenced by several abiotic factors including temperature, luminosity, substrate type, water flow and nutrient content (FANTA et al., 2010; Rosa et al., 2013). Some biotic factors may negatively affect periphyton biomass, such as herbivory and bioturbation caused by aquatic organisms (Wellnitz \& Poff, 2012).

Allochthonous organic matter constitutes the main energy source for the metabolism of streams shaded by riparian vegetation (VANNOTE et al., 1980; Minshall et al., 1983). However, even with the predominance of leaf litter on the streambed, some studies have suggested that the autochthonous production of periphyton constitutes an important food resource for heterotrophic organisms in tropical streams (Brito et al., 2006; Li \& Dudgeon, 2008; LAU et al., 2009). Because of the low quality of the allochthonous organic material available (high $\mathrm{C}: \mathrm{N}$ ratio and toughness), periphytic algae are more palatable for consumers in these ecosystems (BURNS \& WALKER, 2000).

The growth of periphyton facilitates the colonization of substrates by invertebrate scrapers, which have specialized mouthparts to feed on attached algae (WALLACE \& WEBSTER, 1996). These organisms produce fine particulate organic matter through their feces, which can then be used as food resource by collectors (Cummins \& KLUG, 1979). Thus, the spatial distribution and biomass of periphyton can modify the structure of aquatic assemblages associated with different substrates, influencing the organisms that feed directly on these communities (YAFE et al., 2002; QuINTANs et al., 2009), shelter from predators and water flow, and feed on fine particulate organic matter deposited on the periphyton or produced by scrapers (MoulTon et al., 2004; WellnITZ $\&$ PoFF, 2012).

Changes in the riparian vegetation and nutrient input from agricultural activities or pollution sources may increase periphyton primary productivity and biomass in streams (FANTA et al., 2010). In reaches where the riparian vegetation was removed, periphyton algae can support higher production of aquatic invertebrate assemblages, in part because algae are assimilated more efficiently (FULLER et al., 2004). On the other hand, invertebrate diversity tends to be lower in altered streams (Oliveira \& CALlisto, 2010; Kleine et al., 2011; Mesa et al., 2013). According to Debenest et al. (2009), the input of herbicides in stream ecosystems reduces the biomass of periphytic algae, even in environments with good light and nutrient availability.

In this study, we evaluated the growth of periphyton and colonization of rocky substrates by invertebrate assemblages in three forest streams of the same watershed that differ in the conservation level of riparian zones. Assuming that changes in the riparian zones may alter light availability, water temperature and, consequently, the production of periphytic algae, we incubated sterilized cobbles on the substrate of the studied streams and determined the content of chlorophyll- $a$ and the structural composition of invertebrate assemblages over 60 days. We hypothesized that the increase of periphytic biomass would be higher in the most altered stream and invertebrate assemblages associated with the exposed substrates would differ among streams.

\section{MATERIAL AND METHODS}

Study area. The studied streams are located in the headwaters of the Santa Maria da Vitória River, in the municipalities of Santa Leopoldina and Cariacica (Espírito Santo, SE Brazil). The study area contains several fragments of Atlantic Forest surrounded by agricultural areas and livestock pastures (CASOTTI et al., 2015). According with the Köppen's climate classification for Brazil, the regional climate is Humid Subtropical with Hot Summer (Cfa). Daily mean air temperatures and rainfall range between $19-28^{\circ} \mathrm{C}$ and $1000-1600 \mathrm{~mm}$ year $^{-1}$ (Alvares et al., 2013). The forest canopy coverage in each stream was estimated by the analysis of photographs, taken with a digital camera (SONY Steady-Shot DSC-W610) positioned parallel and immediately above the water surface (KORHONEN et al., 2006), using ImageJ Software (US National Institutes of Health, Bethesda, Maryland, USA).

Luxemburgo Stream $\left(20^{\circ} 08^{\prime} 15.6^{\prime \prime} \mathrm{S}-40^{\circ} 35^{\prime} 44.4^{\prime \prime} \mathrm{W}\right.$, $562 \mathrm{~m}$ a.s.1.) is located near small rural properties and extensive banana and Eucalyptus plantations. The reach selected for the study has low canopy cover (40\%), and the substrate is composed basically of cobbles, sand, mud, and some leaf patches covered with fine sediment. Macuco Stream ( $20^{\circ} 01{ }^{\prime} 23.1^{\prime \prime} \mathrm{S}-40^{\circ} 32^{\prime} 58.6^{\prime \prime} \mathrm{W}, 593 \mathrm{~m}$ a.s.1.) is located in a well-preserved fragment of Atlantic Forest and has a developed canopy cover that shades almost $80 \%$ of the streambed. However, a monoculture of Eucalyptus globulus Labill. $\left(\sim 500 \mathrm{~m}^{2}\right)$ and a small rural property are located close to one of the margins of the stream. The substrate is quite heterogeneous and composed of cobbles, gravel, logs, and numerous leaf patches. Pau Amarelo Stream (20 $15^{\prime} 41.3^{\prime \prime} \mathrm{S}$ $-40^{\circ} 30^{\prime} 14.9^{\prime \prime} \mathrm{W}, 426 \mathrm{~m}$ a.s.l.) is located in a protected area (Reserva Biológica Duas Bocas) and has a well-developed canopy cover that shades $90 \%$ of the streambed. The substrate is heterogeneous and composed mostly by cobbles and, in lower number, by gravel, logs and leaf patches. The studied streams formed a gradient of conservation level in the riparian 


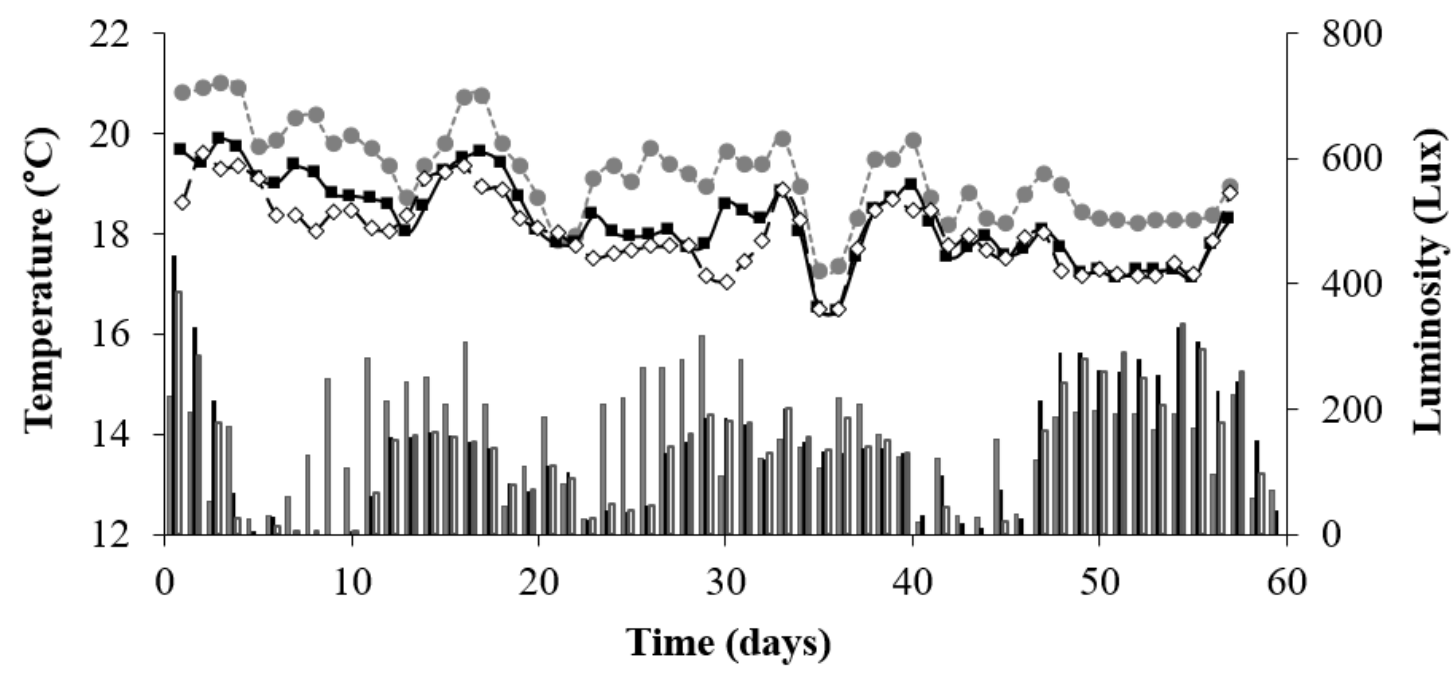

Fig. 1. Daily mean values of water temperature (lines) and luminosity (columns) in Luxemburgo (gray), Macuco (black) and Pau Amarelo (white) streams, state of Espírito Santo, Brazil during the experiment.

zones: Luxemburgo (altered) < Macuco (slightly altered) $<$ Pau Amarelo (preserved).

During the experiment, which lasted from June to August 2012, the streams had well-oxygenated water, with slightly acid $\mathrm{pH}$ and low values of electrical conductivity (Tab. I). The initial content of Nitrogen and Phosphorus in the water ranged between $0.01-0.06 \mathrm{mg} \mathrm{l}^{-1}$ and $0.001-$ $0.010 \mathrm{mg} \mathrm{l}^{-1}$, respectively. Luminosity and water temperature were measured at 30-min intervals by temperature/light data loggers (HOBO UA-002-08, Onset Computer Corporation, Bourne, MA, USA) placed on the streambed of each stream. Daily mean water temperatures were higher in Luxemburgo than in Macuco and Pau Amarelo $\left(\mathrm{F}_{2,168}=31.872, \mathrm{p}<0.001\right.$; Fig. 1). The luminosity varied between $157 \pm 10$ lux in Luxemburgo stream and $128 \pm 13$ lux in Pau Amarelo stream, but did not differ significantly among streams $\left(\mathrm{F}_{2,168}=1.26\right.$, $\mathrm{p}=0.286$ ).

Experimental design. On June $6^{\text {th }}, 2012$, four quadrats of $1 \mathrm{~m}^{2}$ were fixed on the streambed of each stream, using iron bars and colored markers. In each quadrat, we incubated five cobbles of similar shape and size that had been previously collected from the streams, washed and ashed $\left(550^{\circ} \mathrm{C}, 2 \mathrm{~h}\right)$ in the laboratory. These cobbles were used as substrate for the growth of periphytic algae and colonization of aquatic invertebrates. At intervals of 7, 15, 30, 45 and 60 days of incubation, periphyton and invertebrate assemblages were sampled from one incubated cobble in each quadrat, i.e., four cobbles (replicates) in each stream.

At each sampling interval, the invertebrates associated with each incubated cobble were sampled with a Surber sampler $\left(0.09 \mathrm{~m}^{2}, 250 \mu \mathrm{m}\right.$ mesh). These samples were placed in individual plastic bags and taken to the laboratory. Then, each cobble was removed from the respective quadrat for periphyton sampling. Cobbles were placed on individual plastic trays containing stream water and brushed carefully. The extract retained in the trays was stored in covered centrifuge tubes $(50 \mathrm{ml})$ under refrigeration and taken to the laboratory. After the periphyton was removed, the active surface area of each cobble, i.e., the area excluding the lower surface, was determined following Rosa et al. (2013) (Luxemburgo: $174.3 \pm 7.7 \mathrm{~cm}^{2}$; Macuco: $166.26 \pm 10.1 \mathrm{~cm}^{2}$; Pau Amarelo: $\left.154.20 \pm 7.5 \mathrm{~cm}^{2} ; \mathrm{F}_{2,57}=1.39, \mathrm{p}=0.255\right)$.

Sample processing. The chlorophyll- $a$ content was used as an indicator of the growth of periphytic algae on each incubated cobble. In the laboratory, the volume of each periphyton sample, i.e., the extract removed from each cobble (four replicates per sampling interval in each stream), was determined, and then the sample was filtered through

Tab. I. Water physical and chemical properties (mean, maximum and minimum values) of Luxemburgo, Macuco and Pau Amarelo streams, state of Espírito Santo, Brazil during the experiment ( $\mathrm{n}=6$ in situ measurements; *, one single measurement).

\begin{tabular}{lcccccc}
\hline & \multicolumn{2}{c}{ Luxemburgo } & \multicolumn{2}{c}{ Macuco } & \multicolumn{2}{c}{ Pau Amarelo } \\
\cline { 2 - 7 } & Mean & Range & Mean & Range & Mean & Range \\
\hline Width $(\mathrm{m})$ & 6.76 & $6.40-7.30$ & 3.42 & $2.40-4.10$ & 5.78 & $5.00-6.70$ \\
Depth $(\mathrm{m})$ & 0.27 & $0.23-0.34$ & 0.14 & $0.09-0.20$ & 0.23 & $0.21-0.26$ \\
Discharge $\left(\mathrm{m}^{3} \mathrm{~s}^{-1}\right)$ & 0.24 & $0.10-0.26$ & 0.10 & $0.07-0.14$ & 0.43 & $0.31-0.56$ \\
Conductivity $\left(\mu \mathrm{S} \mathrm{cm}^{-2}\right)$ & 26.12 & $24.60-28.10$ & 21.55 & $19.40-26.39$ & 29.86 & $27.60-35.80$ \\
Dissolved $\mathrm{O}_{2}\left(\mathrm{mg} \mathrm{l}^{-1}\right)$ & 8.74 & $8.59-8.89$ & 8.75 & $8.70-8.79$ & 8.39 & $7.89-8.64$ \\
pH & 6.34 & $6.14-7.16$ & 6.59 & $6.17-7.25$ & 6.64 & $6.20-6.80$ \\
Total $\mathrm{N}\left(\mathrm{mg} \mathrm{l}^{-1}\right)^{*}$ & 0.06 & & 0.04 & & 0.01 & $<0.001$ \\
Total P $\left(\mathrm{mg} \mathrm{l}^{-1}\right)^{*}$ & 0.010 & & 0.004 & & & \\
\hline
\end{tabular}


fiberglass filters (GF/F Glass Microfiber Filter, $47 \mathrm{~mm}$, Whatman, Shrewsbury, MA, USA; $0.7 \mu \mathrm{m}$ pore size). The filters were stored individually in covered Petri dishes and frozen $\left(-20^{\circ} \mathrm{C}\right)$. Posteriorly, the pigments were extracted in $90 \%$ acetone for $24 \mathrm{~h}$ at $4^{\circ} \mathrm{C}$ and the filters slurry was centrifuged at $1000 \mathrm{~g}$ for $5 \mathrm{~min}$. Analysis of chlorophyll- $a$ was performed using a multi-wavelength spectrophotometer following EPA's Method 446.0 (ARAR, 1997).

Invertebrate samples were washed over $250-\mu \mathrm{m}$ sieves and fixed with $70 \%$ ethanol. The samples were then sorted, and the invertebrates identified with a stereoscopic microscope $(32 \mathrm{x})$ to the lowest possible taxonomic level (Pes et al., 2005; Mugnai et al., 2010; Trivinho-Strixino, 2011). Invertebrate taxa were assigned to functional feeding groups, following specific classifications for Brazil (CummINs et al., 2005; BAPTISTA et al., 2006) and oven-dried $\left(60^{\circ} \mathrm{C}\right.$, $72 \mathrm{~h}$ ) for biomass determination $(0.01 \mathrm{mg})$.

Data analysis. Data for the density (ind $\mathrm{cm}^{-2}$ ) and biomass $\left(\mathrm{mg} \mathrm{cm}^{-2}\right)$ of the invertebrate assemblages and content of chlorophyll- $a\left(\mu \mathrm{g} \mathrm{cm}^{-2}\right)$ were compared by mixed-design analysis of variance models (split-plot ANOVA), using the streams as a fixed factor and sampling intervals as a random factor. When the assumption of sphericity has been violated (Mauchly test: $p<0.05$ ), degrees of freedom were corrected using Greenhouse-Geisser estimates of sphericity $(\varepsilon<0.75)$. Post-hoc comparisons were carried out using Bonferroni test (ZAR, 2010). Invertebrate richness was compared among streams by Mao-Tau sample-based rarefaction curves with 95\% confidential intervals (CoLwell et al., 2004). To assess the spatial structures of invertebrate assemblages sampled in the studied streams at different sampling intervals, a canonical analysis of principal coordinates (CAP; ANDERSON \& WILLIS, 2003) was performed using the Bray-Curtis resemblance distance matrix (log-transformed data, 999 permutations). Invertebrate taxa with a correlation greater than 0.3 were overlaid as vectors on the CAP plot. A PERMANOVA was used to test for significant differences among the assemblages found in each stream. The Analysis of Indicator Species (DUFRÊNE \& LEGENDRE, 1997) was used to determine if any taxon was characteristic of one group of samples (stream). All statistical analyses were performed using R (R Development Core Team, Vienna, Austria) and Primer 6.0 (Primer-E Ltd, Plymouth, UK).

\section{RESULTS}

In Luxemburgo, the contents of chlorophyll- $a$ indicated rapid growth of periphytic algae on the first 15 days of the experiment (Fig. 2). These values showed low variation until the $45^{\text {th }}$ day and decreased during the last sampling interval. In Macuco and Pau Amarelo, periphyton growth was more continuous throughout the experiment and the highest values were observed during the last sampling interval. However, these values increased faster in Macuco during the first 15 days, while high values were observed in Pau Amarelo after the $45^{\text {th }}$ and $60^{\text {th }}$ days (Fig. 2). The content of chlorophyll- $a$ did not differ among streams, but,

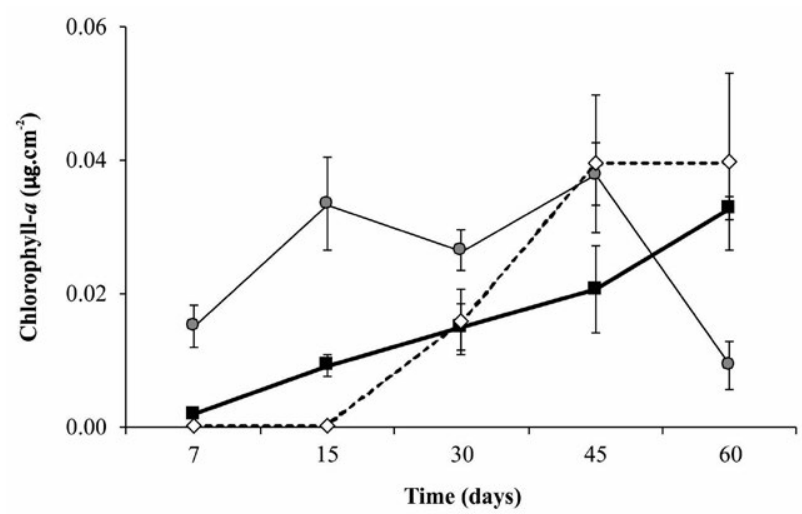

Fig. 2. Contents of chlorophyll- $a$ (mean \pm SE) on the cobbles incubated in Luxemburgo (thin solid line, gray circles), Macuco (thick solid line, black squares) and Pau Amarelo (dashed line, white diamonds) streams, state of Espírito Santo, Brazil.

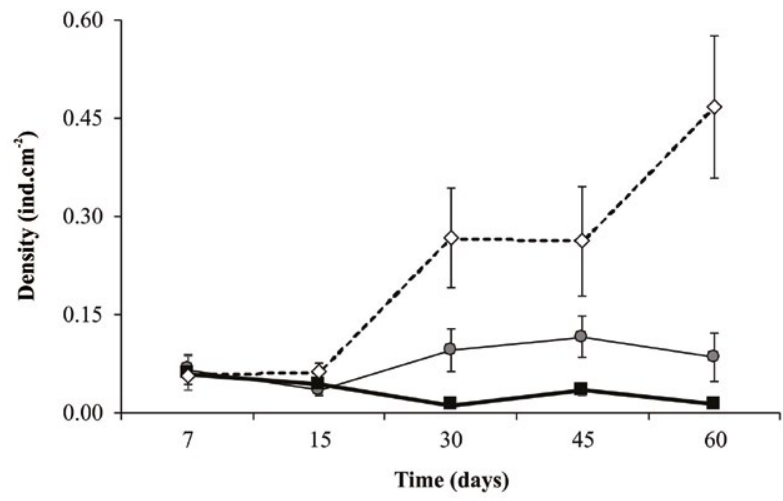

Fig. 3. Values (mean $\pm \mathrm{SE}$ ) of invertebrate density associated with cobbles in Luxemburgo (thin solid line, gray circles), Macuco (thick solid line, black squares) and Pau Amarelo (dashed line, white diamonds) streams, state of Espírito Santo, Brazil.

except for Luxemburgo on day 60, values observed after the first week of the experiment were significantly lower than those of other sampling intervals (Tab. II). The interaction of these two factors (streams $\times$ sampling intervals) was also significant.

The density of invertebrates found associated with cobbles in the studied streams was similar on the first 15 days of the experiment. In Pau Amarelo, values of invertebrate density increased between the $15^{\text {th }}$ and the $60^{\text {th }}$ day $(0.06 \pm$ 0.01 up to $0.47 \pm 0.10$ ind $\mathrm{cm}^{-2} ;$ Fig. 3). These values were intermediate in Luxemburgo $(0.04 \pm 0.01$ up to $0.12 \pm$ 0.03 ind $\mathrm{cm}^{-2}$ ) and low in Macuco, in which the maximum values were observed after the first 7 days of the experiment $\left(0.06 \pm 0.02\right.$ ind $\left.\mathrm{cm}^{-2}\right)$. The values of invertebrate density observed in Pau Amarelo were significantly higher than those observed in Luxemburgo and Macuco; values on the initial sampling intervals ( 7 and 15 days) were lower than on more advanced colonization stages (30, 45 and 60 days; Tab. II). Differences were also observed on the interaction of both factors. In Luxemburgo and Macuco, the maximum values of invertebrate biomass were observed after the first 7 days of incubation $\left(0.04 \pm 0.01\right.$ and $0.03 \pm 0.01 \mathrm{mg} \mathrm{cm}^{-}$ ${ }^{2}$, respectively; Fig. 4), while in Pau Amarelo maximum values were observed on the $15^{\text {th }}$ day $\left(0.09 \pm 0.01 \mathrm{mg} \mathrm{cm}^{-2}\right)$. 
Tab. II. Results from mixed-design analysis of variance models (split-plot ANOVAs) comparing the content of chlorophyll- $a$, and the values of density and biomass of invertebrates associated with cobbles in Luxemburgo, Macuco and Pau Amarelo streams, state of Espírito Santo, Brazil. Streams were used as a fixed factor and sampling intervals as a random factor. Degrees of freedom were corrected using Greenhouse-Geisser estimates of sphericity $(\varepsilon<0.75)$.

\begin{tabular}{|c|c|c|c|c|}
\hline & df & MS & $\mathrm{F}$ & $\mathrm{p}$ \\
\hline \multicolumn{5}{|l|}{ Chlorophyll- $a$ content } \\
\hline \multicolumn{5}{|l|}{ Between-subjects } \\
\hline Stream & 2 & 0.000 & 1.51 & 0.27 \\
\hline Error & 9 & 0.000 & & \\
\hline \multicolumn{5}{|l|}{ Within-subjects } \\
\hline Sampling interval & 1 & 0.004 & 16.09 & $<0.01$ \\
\hline Stream $\times$ Samp. interval & 2 & 0.002 & 6.64 & 0.02 \\
\hline Error & 9 & 0.000 & & \\
\hline \multicolumn{5}{|l|}{ Invertebrate density } \\
\hline \multicolumn{5}{|l|}{ Between-subjects } \\
\hline Stream & 2 & 0.196 & 35.56 & $<0.01$ \\
\hline Error & 9 & 0.006 & & \\
\hline \multicolumn{5}{|l|}{ Within-subjects } \\
\hline Sampling interval & 1 & 0.143 & 14.75 & $<0.01$ \\
\hline Stream $\times$ Samp. interval & 2 & 0.141 & 14.62 & $<0.01$ \\
\hline Error & 9 & 0.010 & & \\
\hline \multicolumn{5}{|l|}{ Invertebrate biomass } \\
\hline \multicolumn{5}{|l|}{ Between-subjects } \\
\hline Stream & 2 & 0.005 & 9.81 & $<0.01$ \\
\hline Error & 9 & 0.000 & & \\
\hline \multicolumn{5}{|l|}{ Within-subjects } \\
\hline Sampling interval & 1 & 0.005 & 8.54 & 0.01 \\
\hline Stream $\times$ Samp. interval & 2 & 0.000 & 0.20 & 0.82 \\
\hline Error & 9 & 0.001 & & \\
\hline
\end{tabular}

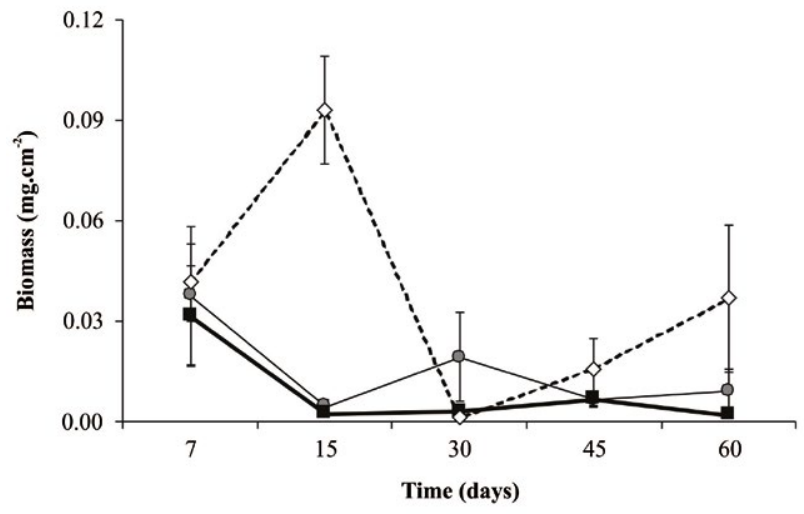

Fig. 4. Values (mean $\pm \mathrm{SE}$ ) of invertebrate biomass associated with cobbles in Luxemburgo (thin solid line, gray circles), Macuco (thick solid line, black squares) and Pau Amarelo (dashed line, white diamonds) streams, state of Espírito Santo, Brazil.

Invertebrate biomass was higher in Pau Amarelo than in Luxemburgo and Macuco; values observed on the $15^{\text {th }}$ day of the experiment were higher than those observed on other sampling intervals (Fig. 4; Tab. II). The interaction of both factors was not significant.

The richness of invertebrate assemblages varied among streams and the number of taxa was higher in Pau Amarelo (29), intermediate in Macuco (26) and lower in Luxemburgo (24). Taxonomic richness estimates using sample rarefaction curves showed that Mao-Tau estimator stabilized after approximately 20 samples in Pau Amarelo

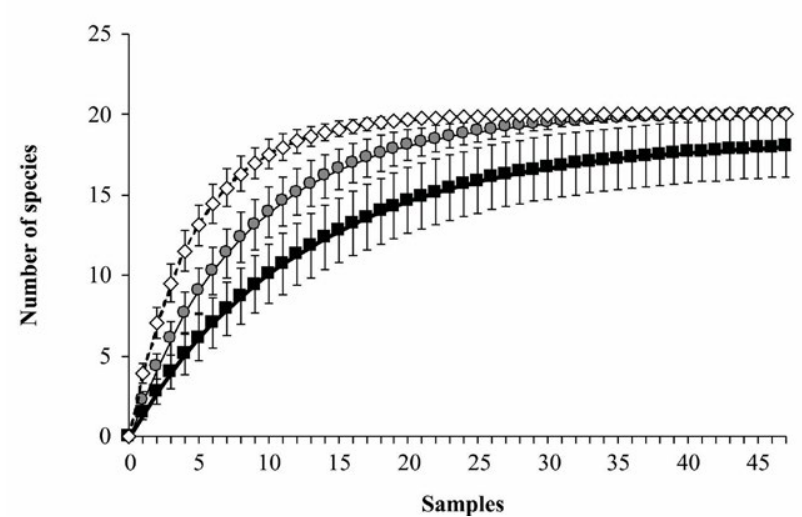

Fig. 5. Species accumulation curves (Mao-Tau sampled based rarefaction with $95 \%$ confidence intervals) of invertebrates associated with cobbles in Luxemburgo (thin solid line, gray circles), Macuco (thick solid line, black squares) and Pau Amarelo (dashed line, white diamonds) streams, state of Espírito Santo, Brazil.

and 35 samples in Luxemburgo (Fig. 5). In Macuco, the estimator did not stabilize but, after 40 samples, the estimated numbers of taxa were similar to other streams.

In total, 954 invertebrates belonging to 36 taxa were found (Tab. III); the Class Insecta accounted for $98 \%$. The number of organisms found associated with cobbles was higher in Pau Amarelo (579 ind.), intermediate in Luxemburgo (277 ind.) and lower in Macuco (98 ind.). Chironominae (Diptera) was the most abundant taxon in Luxemburgo and Pau Amarelo (37 and 42\% respectively), while Simuliidae (Diptera) dominated invertebrate assemblages in Macuco 
Tab. III. Density (ind $\mathrm{cm}^{-2}$ ) of the invertebrate taxa associated with cobbles in Luxemburgo, Macuco and Pau Amarelo streams, state of Espírito Santo, Brazil (FFG, functional feeding group; Scr., scrapers; Gat.-Col., gathering-collectors; Pre., predators; Shr., shredders; Fil.-Col., filtering-collectors; -, absent; *, multiple feeding habits; ?, no information available).

\begin{tabular}{|c|c|c|c|c|}
\hline \multirow{2}{*}{ Taxa } & \multirow{2}{*}{ FFG } & \multicolumn{3}{|c|}{ Streams } \\
\hline & & Luxemburgo & Macuco & Pau Amarelo \\
\hline COLLEMBOLA & Gat.-Col. & 0.008 & 0.006 & 0.008 \\
\hline \multicolumn{5}{|l|}{ EPHEMEROPTERA } \\
\hline Baetidae & Scr. & 0.216 & 0.070 & 0.337 \\
\hline Leptohyphidae & Scr. & 0.203 & 0.066 & 0.334 \\
\hline Leptophlebiidae & Gat.-Col. & 0.023 & & 0.245 \\
\hline \multicolumn{5}{|l|}{ ODONATA } \\
\hline Calopteterygidae & Pre. & 0.006 & & \\
\hline Gomphidae & Pre. & 0.006 & 0.013 & \\
\hline Libellulidae & Pre. & 0.005 & 0.008 & \\
\hline Megapodagrionidae & Pre. & 0.044 & 0.053 & 0.075 \\
\hline \multicolumn{5}{|l|}{ PLECOPTERA } \\
\hline Perlidae & Pre. & 0.005 & 0.034 & 0.042 \\
\hline \multicolumn{5}{|l|}{ HEMIPTERA } \\
\hline Gerridae & Pre. & & 0.006 & 0.004 \\
\hline Naucoridae & Pre. & 0.015 & & \\
\hline Veliidae & Pre. & 0.014 & 0.021 & 0.052 \\
\hline \multicolumn{5}{|l|}{ COLEOPTERA } \\
\hline Elmidae (larva) & Gat.-Col. & 0.167 & 0.036 & 0.230 \\
\hline Elmidae (adult) & Scr. & 0.021 & 0.012 & \\
\hline Psephenidae & Scr. & & & 0.006 \\
\hline \multicolumn{5}{|l|}{ TRICHOPTERA } \\
\hline \multicolumn{5}{|l|}{ Calamoceratidae } \\
\hline Phylloicus major & Shr. & 0.006 & 0.006 & 0.019 \\
\hline Glossosomatidae & Scr. & & & 0.020 \\
\hline Helichopsychidae & Scr. & 0.006 & & 0.206 \\
\hline Hydropsychidae & Fil.-Col. & 0.031 & 0.014 & 0.133 \\
\hline Hydroptilidae & Scr. & & & 0.104 \\
\hline Leptoceridae & Gat.-Col./Shr. & & & 0.083 \\
\hline Odontoceridae & Scr. & & 0.009 & 0.012 \\
\hline Philopotamidae & Fil.-Col. & 0.026 & 0.006 & 0.007 \\
\hline Polycentropodidae & Fil.-Col. & 0.020 & 0.009 & 0.040 \\
\hline \multicolumn{5}{|l|}{ DIPTERA } \\
\hline Ceratopogonidae & Pre./Gat.-Col. & & 0.007 & 0.021 \\
\hline \multicolumn{5}{|l|}{ Chironomidae } \\
\hline Chironominae & $*$ & 0.594 & 0.085 & 1.863 \\
\hline Stenochironomus & Shr. & & 0.007 & \\
\hline Orthocladiinae & $*$ & 0.048 & 0.018 & 0.281 \\
\hline Tanypodinae & Pre. & 0.026 & 0.020 & 0.084 \\
\hline Empididae & Pre. & & 0.014 & 0.045 \\
\hline Psychodidae & Gat.-Col. & & & 0.017 \\
\hline Simuliidae & Fil.-Col. & 0.064 & 0.122 & 0.066 \\
\hline Tipulidae & Pre./Shr. & & 0.005 & \\
\hline \multicolumn{5}{|l|}{ LEPIDOPTERA } \\
\hline Pyralidae & $?$ & & & 0.006 \\
\hline \multicolumn{5}{|l|}{ ANNELIDA } \\
\hline Oligochaeta & Gat.-Col. & 0.018 & 0.007 & 0.042 \\
\hline \multicolumn{5}{|l|}{ ACARINA } \\
\hline Hydracarina & Pre. & 0.020 & 0.006 & 0.033 \\
\hline Total abundance & & 277 & 98 & 579 \\
\hline
\end{tabular}




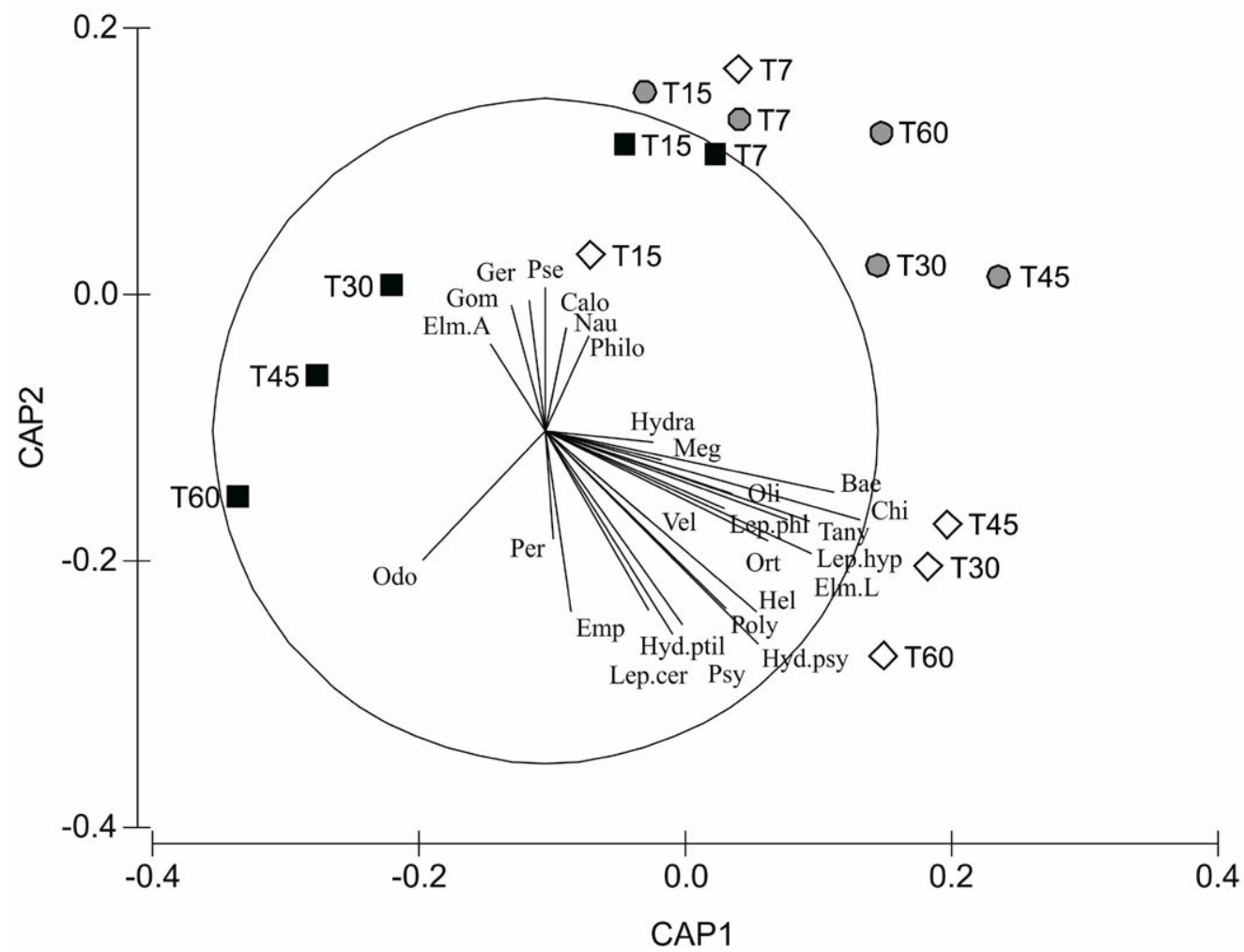

Fig. 6. Canonical analysis of principal coordinates (CAP) of invertebrates associated with cobbles in Luxemburgo (gray circles), Macuco (black squares) and Pau Amarelo (white diamonds) streams, state of Espírito Santo, Brazil. Only taxa vectors with correlations $>0.3$ are included in the plot. T7, T15, T30, T45 and T60: sampling intervals (Bae: Baetidae; Calo, Calopterygidae; Chi, Chironominae; Elm.A, Elmidae adult; Elm.L, Elamidae larva; Emp, Empididae; Ger, Gerridae; Gom, Gomphidae; Hel, Helichopsychidae; Hydra, Hydracarina; Hyd.psy, Hydropsychidae; Hyd.ptil, Hydroptilidae; Lep.cer, Leptoceridae; Lep.hyp, Leptohyphidae; Lep.phl, Leptophlebiidae; Meg, Megapodagrionidae; Nau, Naucoridae; Odo, Odontoceridae; Oli, Oligochaeta; Ort, Orthocladiinae; Per, Perlidae; Philo, Philopotamidae; Poly, Polycentropodidae; Pse, Psephenidae; Psy, Psychodidae; Tany, Tanypodinae; Vel, Veliidae).

(18\%). Leptohyphidae and Baetidae (Ephemeroptera) exhibited high densities in all streams $(7-13 \%)$, and Elmidae larvae (Coleoptera) exhibited higher densities in Luxemburgo (23\%). The maximum values of relative biomass of scrapers were observed after 15 and 30 days in Pau Amarelo and Macuco (42 and 38\%, respectively), while in Luxemburgo maximum values were observed after 60 days $(60 \%)$. This was the only sampling interval in which scrapers accounted for more than $50 \%$ of the biomass of the invertebrate assemblages associated with cobbles.

The CAP ordination plot revealed that invertebrate assemblages on the initial sampling intervals formed a separate group (Fig. 6), while the assemblages sampled after the $15^{\text {th }}$ day in each stream formed individual clusters. The stream effect on invertebrate assemblages was also supported

Tab. IV. Results of the analysis of indicator species for the assemblages associated with cobbles in Pau Amarelo stream, state of Espírito Santo, Brazil. Only taxa with significant results are shown.

\begin{tabular}{lcc}
\hline Taxa & Indicator Value & $\mathrm{p}$ - value \\
\hline Leptophlebiidae & 0.770 & 0.005 \\
Hydroptilidae & 0.742 & 0.005 \\
Helichopsychidae & 0.661 & 0.005 \\
Leptoceridae & 0.592 & 0.005 \\
Orthocladiinae & 0.667 & 0.005 \\
\hline
\end{tabular}

by the PERMANOVA results (Pseudo-F $=2.21, \mathrm{p}<0.01$ ). Comparing to the initial assemblages of studied streams that were structured by few invertebrate taxa (Philopotamidae [Trichoptera], Naucoridae [Hemiptera], Calopterygidae [Odonata] and Psephenidae [Coleoptera]), the assemblages sampled in Pau Amarelo after the $15^{\text {th }}$ day were structured by a high number of taxa (17), which showed high densities or were found only in this stream (Fig. 6). However, the Analysis of Indicator Species indicated that only five taxa showed specificities with the assemblages found in Pau Amarelo (Tab. IV). No taxa proved to be an indicator of the assemblages found in Luxemburgo and Macuco.

\section{DISCUSSION}

Invertebrate assemblages found associated with the exposed substrates differed among the studied streams. After the initial stage of the experiment (first 15 days), cobbles incubated in Pau Amarelo were colonized by a high number of invertebrate taxa and the values of density increased until the end of the experiment. In Luxemburgo, invertebrate assemblages were dominated by taxa that are tolerant (Baetidae and Elmidae) or resistant (Chironominae) to anthropogenic changes, while lowest levels of invertebrate densities and taxa richness were observed in Macuco. 
In spite of the conservation level in the riparian zones did not influence the biomass of periphyton, measured indirectly through the content of chlorophyll- $a$, the growth of periphytic algae was faster in the most altered stream. Shading is one of the main factors controlling periphyton biomass (RIER et al., 2014), and sunlight may enhance the effects of leaf-litter leachates on algae growth (LovATT et al., 2014). In spite of the differences in canopy cover, luminosity levels did not differ between the streams. However, during most of the experiment, mean daily luminosity was higher in Luxemburgo. The warm water temperatures in this stream are probably related to changes in the riparian vegetation that allowed more sunlight to reach the stream channel. BowLER et al. (2012), working in European streams, observed that water temperatures were positively correlated with light input.

The rapid growth of periphyton in Luxemburgo probably resulted from higher water temperature, luminosity and dissolved nutrients in the water column. Temperature is a key factor in the development of algal biomass because it regulates cellular metabolism, tending to optimize growth rates (Bowes et al., 2007). Normally, nitrogen and phosphorus act as limiting nutrients for algae and periphyton growth in stream ecosystems (MURDocK et al., 2011; Rosa et al., 2013). In streams located near agricultural areas, the periphyton production can be increased by input of fertilizers leached from surrounding areas (CONLEY et al., 2009). On the other hand, as we did not observe any change in water flow and substrate revolvement during the experiment, the decrease in the content of chlorophyll- $a$ observed on the end of the experiment in Luxemburgo may be related to an increase in consumption of algae by invertebrate scrapers, which after 60 days represented more than $50 \%$ of the biomass of invertebrates found in Luxemburgo. According to KIFFNEY et al. (2003), Moulton et al. (2004) and Murdock et al. (2011), herbivory by aquatic insects, crustaceans and fish can significantly reduce algal biomass in streams by a topdown control of periphyton communities (WINKELMANN $e t$ al., 2014).

In Pau Amarelo, the development of periphytic algae directly influenced the invertebrate density on the incubated cobbles, since periphyton communities provide a more stable habitat and food resources (BENETTI et al., 2014). The elevated densities of chironomid larvae in the studied streams reflect the ability of rapid substrate colonization of this group, which includes species with different feeding habits that occur in ecosystems with a wide range of environmental conditions (Rosa et al., 2011). According to OlIVEIRA \& NeSSIMIAN (2010), chironomid larvae may feed on fine particulate organic matter, algae and small invertebrates associated with periphyton. The high abundances of larvae of Elmidae in Luxemburgo and Pau Amarelo could be explained by their morphological adaptations that allow them to attach to and feed on substrates under highflow conditions (ELLIOTt, 2008).

Contrary to our expectations, the biomass of aquatic invertebrates did not increase over the experiment. In addition, the values varied widely in Pau Amarelo. These results suggest that other factors, not directly related to periphyton growth, and also influenced the colonization of cobbles by invertebrates. Predation, for example, might have been an important structuring factor for the assemblages (MCINTOSH \& TOWNSEND, 1996; FAIRCHILD \& HOLOMUZKI, 2005; HolOMUZKi et al., 2010). The studied streams contain macroconsumers (crabs and shrimps) that may control invertebrate communities, as observed by LOURENÇOAMORIm et al. (2014) and Costa et al. (2016) in Atlantic Forest streams located in the state of Rio de Janeiro and Espírito Santo, Brazil.

Comparing with the initial sampling intervals, the structural composition of invertebrate assemblages after the first month of the experiment differed more in Pau Amarelo. Since the growth of periphyton increased substantially after the $15^{\text {th }}$ day in this stream, the exposed substrate changed continuously during sampling intervals (MUNN et al., 2010), meeting the requirements of more different taxa. Pau Amarelo stream has a heterogeneous streambed inhabited by abundant and diverse assemblages of invertebrates (Flávio Mendes, pers. comm.), which may have acted as sources of colonizing organisms for the incubated cobbles (BONADA et al., 2006). Moreover, four taxa that were proved to be indicators of the invertebrate assemblages in this stream belong to Ephemeroptera and Trichoptera, which are normally abundant in natural streams, while they are found in reduced abundances or absent in streams with different levels of alterations (AMARAL et al., 2015).

In conclusion, our results showed that changes in the riparian zones of Atlantic Forest streams did not affect the content of chlorophyll- $a$ on rocky substrates but periphytic algae grew faster in the most altered stream. The growth of periphyton influenced the density and structural composition of invertebrate assemblages associated with cobbles, because differences were observed only after the initial sampling intervals, when values of chlorophyll- $a$ increased substantially. These results partially support the proposed hypothesis and conform to the notion of the importance of periphyton communities for the colonization of exposed substrates by aquatic invertebrates. In addition to herbivory, other species interactions, such as predation, may also have influenced the colonization process. The relationship between the production of periphytic algae and invertebrate assemblages is important for understanding energy flow in forest streams, and at the same time, for evaluating the consequences of anthropogenic changes in ecosystem functioning and aquatic communities.

Acknowledgements. We are grateful to our colleagues from the Laboratório de Ecologia de Insetos Aquáticos (Universidade Vila Velha) for assistance in the field, Carlos Burke for the logistical facilities, and Janet Reid for reviewing the English style. The Fundação de Amparo à Pesquisa e Inovação do Espírito Santo (FAPES; Proc. \# 61861480/2013) and the Conselho Nacional para o Desenvolvimento Científico e Tecnológico (CNPq; Proc. \# 449957/2014-4) supported this study. FAPES provided Marcelo Moretti with a research fellowship (T.O. \# 0264/2016). 


\section{REFERENCES}

Alvares, C. A.; Stape, J. L.; Sentelhas, P. C.; GonÇalves, J. L. M. \& SparoveK, S. 2013. Köppen's climate classification map for Brazil. Meteorologische Zeitschrift 22:711-728.

Amaral, P. H. M.; Silveira, L. S.; Rosa, B. F. J. V.; Oliveira, V. C. \& ALVES, R. G. 2015. Influence of habitat and land use on the assemblages of Ephemeroptera, Plecoptera, and Trichoptera in neotropical streams. Journal of Insect Science 15:1-7.

Anderson, M. J. \& Willis, T. J. 2003. Canonical analysis of principal coordinates: A useful method of constrained ordination for ecology. Ecology 84:511-525.

ARAR, E. J. 1997. Method 446.0, In vitro determination of chlorophylls a, b, c1, $+\mathbf{c} 2$ and pheopigments in marine and freshwater algae by visible spectrophotometry. Washington DC, Environmental Protection Agency. 26p.

Baptista, D. F.; Buss, D. F.; Dias, L. G.; Nessimian, J. L.; Da Silva, E. R. \& Neto, A. H. A. D. M. 2006. Functional feeding groups of Brazilian Ephemeroptera nymphs: ultrastructure of mouthparts. International Journal Limnology 42:87-96.

Benetti, C. J.; PÉrez-Bilbao, A. \& Garrido, J. 2014. The determination of food sources for invertebrates in four ponds in NW Spain using stable isotope analysis. Limnetica 33:86-106.

Bonada, N.; Prat, N.; Resh, V. H. \& Statzner, B. 2006. Developments in aquatic insect biomonitoring: a comparative analysis of recent approaches. Annual Review of Entomology 51:495-523.

Bowes, M. J.; Smith, J. T.; Hilton, J.; Sturt, M. M. \& Armitage, P. D. 2007. Periphyton biomass response to changing phosphorus concentrations in a nutrient-impacted river: a new methodology for phosphorus target setting. Canadian Journal of Fisheries and Aquatic Sciences 64:227238.

Bowler, D. E.; Mant, R.; OrR, H.; Hannah, D. M. \& Pullin, A. S. 2012. What are the effects of wooded riparian zones on stream temperature? Environmental Evidence 1:1-9.

Brito, E. F.; Moulton, T. P.; De Souza, M. L. \& Bunn, S. E. 2006. Stable isotope analysis indicates microalgae as the predominant food source of fauna in a coastal forest stream, south-east Brazil. Austral Ecology 31:623-633.

Burns, A. \& WaLKer, K. F. 2000. Biofilms as food for decapods (Atyidae, Palaemonidae) in the River Murray, South Australia. Hydrobiologia 437:83-90.

Casotti, C. G.; Kiffer JR, W. P.; Costa, L. C.; Rangel, J. V.; Casagrande, L. C. \& MoretTI, M. S. 2015. Assessing the importance of riparian zones conservation for leaf decomposition in streams. Brazilian Journal of Nature Conservation 13:178-182.

Ceneviva-Bastos, M. \& Casatti, L. 2014. Shading effects on community composition and food web structure of a deforested pasture stream: Evidences from a field experiment in Brazil. Limnologica 46:9-21.

Colwell, R. K.; MAO, C. X. \& Chang, J. 2004. Interpolating, extrapolating, and comparing incidence-based species accumulation curves. Ecology 85:2717-2727.

Conley, D. J.; Paerl, H. W.; Howarth, R. W.; Boesch, D. F.; Seitzinger, S. P.; Havens, K. E.; Lancelot, C. \& LiKens, G. E. 2009. Controlling eutrophication: Nitrogen and phosphorus. Science 323:1014-1015.

Costa, L.; Kiffer JR, W. P.; Casotti, C.; Rangel, J. \& Moretti, M. 2016. Influence of Trichodactylus fluviatilis on leaf breakdown in streams: Understanding the role of freshwater crabs in detritus-based food webs. Zoological Studies 54:1-8.

Cummins, K. W. \& Klug, M. J. 1979. Feeding ecology of stream invertebrates. Annual Review of Ecology, Evolution, and Systematics 10:147-172.

Cummins, K. W.; Merritt, R. W. \& Andrade, P. C. N. 2005. The use of invertebrate functional groups to characterize ecosystem attributes in selected streams and rivers in South Brazil. Studies on Neotropical Fauna and Environment 40:69-89.

Debenest, T.; Pinelli, E.; Coste, M.; Silvestre, J.; Mazzella, N.; Madigou, C. \& Delmas, F. 2009. Sensitivity of freshwater periphytic diatoms to agricultural herbicides. Aquatic Toxicology 93:11-17.

DufrêNe, M. \& LEGENDRE, P. 1997. Species assemblages and indicator species: The need for a flexible asymmetrical approach. Ecological Monographs 67:345-366.
ElliotT, J. M. 2008. The ecology of riffle beetles (Coleoptera: Elmidae). Freshwater Review 1:189-203.

Fairchild, M. P. \& HolomuzKi, J. R. 2005. Multiple predator effects on microdistributions, survival, and drift of stream hydropsychid caddisflies. Journal of the North American Benthological Society 24:101-112.

FAnTA, S. E.; Hill, W. R.; Smith, T. B. \& Roberts, B. J. 2010. Applying the light: nutrient hypothesis to stream periphyton. Freshwater Biology 55:931-940.

Feminella, J. W. \& Hawkins, C. P. 1995. Interactions between stream herbivores and periphyton: A quantitative analysis of past experiments. Journal of the North American Benthological Society 14:465-509.

Fuller, R. L.; KenNedy, B. P. \& Nielsen, C. 2004. Macroinvertebrate responses to algal and bacterial manipulations in streams. Hydrobiologia 523:113-126.

Holomuzki, J. R.; Feminella, J. W. \& Power, M. E. 2010. Biotic interactions in freshwater benthic habitats. Journal of the North American Benthological Society 29:220-244.

KiffNeY, P. M.; Richardson, J. S. \& Bull, J. P. 2003. Responses of periphyton and insects to experimental manipulation of riparian buffer width along forest streams. Journal of Applied Ecology 40:1060-1076.

Kleine, P.; Trivinho-Strixino, S. \& Corbi, J. J. 2011. Relationship between banana plant cultivation and stream macroinvertebrate communities. Acta Limnologica Brasiliensia 23:344-352.

Korhonen, L.; Korhonen, K. T.; Rautiainen, M. \& Stenberg, P. 2006. Estimation of forest canopy cover: A comparison of field measurement techniques. Silva Fennica 40:577-588.

LARNED, S. T. 2010. A prospectus for periphyton: recent and future ecological research. Journal of the North American Benthological Society 29:182-206.

LAU, D. C. P.; LeunG, K. M. Y. \& DudGeON, D. 2009. Are autochthonous foods more important than allochthonous resources to benthic consumers in tropical headwater streams? Journal of the North American Benthological Society 28:426-439.

Li, A. O. Y. \& DUdGEON, D. 2008. Food resources of shredders and other benthic macroinvertebrates in relation to shading conditions in tropical Hong Kong streams. Freshwater Biology 53:2011-2025.

Lourenço-Amorim, C.; Neres-Lima, V.; Moulton, T. P.; Sasada-Sato, C. Y.; Oliveira-Cunha, P. \& Zandonà, E. 2014. Control of periphyton standing crop in an Atlantic Forest stream: the relative roles of nutrients, grazers and predators. Freshwater Biology 59:2365-2373.

Lovatt, C.; Kominoski, J. S.; SAKamaki, T.; Macleod, B. \& Richardson, J. S. 2014. Leaf-litter leachate and light interactively enhance accrual of stream biofilms. Fundamental and Applied Limnology 184:297-306.

McIntosh, A. R. \& Townsend, C. R. 1996. Interactions between fish, grazing invertebrates and algae in a New Zealand stream: A trophic cascade mediated by fish-induced changes to grazer behavior? Oecologia 108:174-181.

Mesa, L. M.; Reynaga, M. C.; Correa, M. V. \& Sirombra, M. G. 2013. Effects of anthropogenic impacts on benthic macroinvertebrates assemblages in subtropical mountain streams. Iheringia Série Zoologia 103:342-349.

Minshall, G. W.; Petersen, R. C.; Cummins, K. W.; Bott, T. L.; Sedell, J. R.; Cushing, C. E. \& VANnOte, R. L. 1983. Interbiome comparison of stream ecosystem dynamics. Ecological Monographs 53:1-25.

Moulton, T. P.; De Souza, M. L.; Silveira, R. M. L. \& Krsulović, F. A. M. 2004. Effects of ephemeropterans and shrimps on periphyton and sediments in a coastal stream (Atlantic forest, Rio de Janeiro, Brazil). Journal of the North American Benthological Society 23:868-881.

Moulton, T. P.; Lourenço-Amorim, C.; Sasada-Sato, C. Y.; NeresLima, V. \& Zandonì, E. 2015. Dynamics of algal production and ephemeropteran grazing of periphyton in a tropical stream. International Review of Hydrobiology 99:1-8.

Mugnai, R.; Nessimian, J. L. \& Baptista, D. F. 2010. Manual de Identificação de Macroinvertebrados Aquáticos do Estado do Rio de Janeiro. Rio de Janeiro, Technical Books. 174p.

MunN, M.; Frey, J. \& Tesoriero, A. 2010. The influence of nutrients and physical habitat in regulating algal biomass in agricultural streams. Environmental Management 45:603-615.

Murdock, J. N.; Dodds, W. K.; Gido, K. B. \& Whiles, M. R. 2011. Dynamic influences of nutrients and grazing fish on periphyton during 
recovery from flood. Journal of the North American Benthological Society 30:331-345.

Oliveira, A. \& Callisto, M. 2010. Benthic macroinvertebrates as bioindicators of water quality in an Atlantic forest fragment. Iheringia Série Zoologia 100:291-300.

Oliveira, A. L. H. \& Nessimian, J. L. 2010. Spatial distribution and functional feeding groups of aquatic insect communities in Serra da Bocaina streams, southeastern Brazil. Acta Limnologica Brasiliensia 22:424-441.

Pes, A. M. O.; HamadA, N. \& Nessimian, J. L. 2005. Chaves de identificação de larvas para famílias e gêneros de Trichoptera (Insecta) da Amazônia Central, Brasil. Revista Brasileira de Entomologia 49:181-204.

Quintans, F.; Scasso, F.; Loureiro, M. \& Yafe, A. 2009. Diet of Cnesterodon decemmaculatus (Poeciliidae) and Jenynsia multidentata (Anablepidae) in a hypertrophic shallow lake of Uruguay. Iheringia, Série Zoologia 99:99-105.

Rier, S. T.; ShIRVINSKI, J. M. \& KineK, K. C. 2014. In situ light and phosphorus manipulations reveal potential role of biofilm algae in enhancing enzyme-mediated decomposition of organic matter in streams. Freshwater Biology 59:1039-1051.

Rosa, B. F. J. V.; DE Oliveira, V. C. \& Alves, R. G. 2011. Structure and spatial distribution of the Chironomidae community in mesohabitats in a first order stream at the Poço D'Anta Municipal Biological Reserve in Brazil. Journal of Insect Science 11:1-13.

Rosa, J.; Ferreira, V.; Canhoto, C. \& Graça, M. A. S. 2013. Combined effects of water temperature and nutrients concentration on periphyton respiration - implications of global change. International Review of Hydrobiology 98:14-23.

Schneck, F.; Schwarzbold, A. \& Melo, A. S. 2013. Substrate roughness, fish grazers, and mesohabitat type interact to determine algal biomass and sediment accrual in a high-altitude subtropical stream. Hydrobiologia 711:165-173.

Trivinho-Strixino, S. 2011. Larvas de Chironomidae. Guia de Identificação. São Carlos, Universidade Federal de São Carlos. 371p. Vannote, R. L.; Minshall, G. W.; Cummins, K. W.; Sedell, J. R. \& Cushing, C. E. 1980. The River Continuum Concept. Canadian Journal of Fisheries and Aquatic Sciences 37:130-137.

Yafe, A.; Loureiro, M.; Scasso, F. \& Quintans, F. 2002. Feeding of two Cichlidae species (Perciformes) in a hypertrophic urban lake. Iheringia Série Zoologia 92:73-79.

WALLACE, J. B. \& WeBsteR, J. R. 1996. The role of macroinvertebrates in stream ecosystem function. Annual Review of Entomology 41:115139.

Wellnitz, T. \& Poff, L. N. 2012. Current-mediated periphytic structure modifies grazer interactions and algal removal. Aquatic Ecology 46:521-530.

Winkelmann, C.; Schneider, J.; Mewes, D.; Schmidt, S. I.; WorischKa, S.; Hellmann, C. \& Benndorf, J. 2014. Top-down and bottom-up control of periphyton by benthivorous fish and light supply in two streams. Freshwater Biology 59:803-818.

ZAR, J. H. 2010. Biostatistical Analysis. Upper Saddle River, Pearson Prentice-Hall. 944p. 